\title{
SUSTAINABLE URBAN EVENT PRACTICE: THE ROLE OF CORPORATE SPONSORS WITHIN GAUTENG
}

\author{
Felicite Ann Fairer-Wessels \& Nicolette Malberbe \\ Department of Tourism Management \\ University of Pretoria
}

Globally, academics, industry professionals, governments and societies are directing their attention to the issue of global warming and are engaged in efforts to conserve the natural resources of the earth. This has led to the introduction of the concept of sustainability. Lately, the event sector as part of the tourism industry, is being viewed as playing an increasing role in climate change. However, sustainability does not only entail conservation of the natural environment; it also involves the socio-cultural and the economic environment. Events have been found to positively contribute to the economy and the social-cultural environment as well. As little has been published regarding sustainable urban event practice in South Africa, this research aims to establish a greater comprehension of sustainable event practice and the significance thereof. In-depth interviews with corporate events sponsors within the Gauteng region found that these sponsors play an important role in promoting sustainable urban event practice, in terms of enlightening the public and the event companies on sustainability. Due to consumer association with the sponsor and the increased market reach they offer to the event, sponsors can increase awareness and interest in the event, and in doing so influence customers' perceptions on sustainable event practice. Sustainability is a significant issue and is growing in importance. It is essential that the sponsors and managers of event companies work together to develop sustainable urban event guidelines and policies and a formal accreditation programme within the industry.

Keywords: Sustainable urban events, events, event sponsors, sponsorships, sustainable tourism, Gauteng, South Africa

\section{INTRODUCTION}

Climate change and environmental conservation have been the topics of many debates and discussions, for example the Copenhagen Climate Change Conference in 2009 and the $18^{\text {th }}$ Global Warming International Conference and Expo in 2007. With the world's human population increasing at a rapid rate and commanding a growing demand for 
natural resources; greater than which the earth can provide for (Reid, 2006:208), the importance of conserving the earth's resources is far greater than before. People the world over are more environmentally aware and concerned about their carbon footprint that can be owed to increased media coverage and exposure on this topic (Dickson \& Arcodia, 2010:236). Sustainability has become a worldwide concept that addresses the issue of global warming and the degradation of natural resources, and pressure is on organisations, governments and communities to minimise harmful impacts on the environment and increase environmental protection (Dickson \& Arcodia, 2010:236).

Studies have been carried out concerning tourism, climate change and sustainability (Budeanu, 2005:89-97; Hunter \& Shaw, 2007:46-57) and the role of the tourism industry in these as well as in the depletion of the natural environment has been scrutinised (Dickson \& Arcodia 2010:236). The event sector as part of the tourism industry has of late attracted attention as generating substantial waste and impacting negatively on the environment. Consequently recent research has focused on the impacts of events on the environment (Collins, Jones \& Munday, 2009:828-837; Laing \& Frost, 2010:261-267) although little research has focused on sustainable event practice.

Sustainability does not only concern the environment, it also involves socio-cultural and economic aspects. As previous research on events has focused only on the social, economic and/or environmental impacts of events (Collins et al., 2009:828-837; Gratton, Shibli, \& Coleman, 2005:233-247; Gursoy, Kim \& Uysal, 2004:171-181), this study has bearing as the need to investigate sustainable event practice as an integrated concept that addresses social, economic and environmental sustainability is evident, especially to establish sustainable guidelines and policies custom-made to individual events (Dickson \& Arcodia, 2010:242-243). To establish a sustainability certification programme within the event, event companies and sponsors need to realise the importance of sustainable event practice to ensure long-term success and minimise negative impacts on both natural and socio-cultural environments.

The role of corporate sponsors in promoting sustainable event practice is explored and investigated in this study. More specifically, to answer questions such as: 
- what the role is of corporate sponsors in promoting sustainable event practice and how do they create public awareness?; and

- how corporate sponsors can enlighten event companies on the importance of sustainable event practice, and encourage them to pursue it?

A purposeful sampling method was used in which specific corporate event sponsors within the Gauteng region were selected. Individual employees (managerial and/or nonmanagerial) employed in the marketing and sponsorship department as the units of analysis were interviewed in-depth.

\section{OVERVIEW OF THE EVENT INDUSTRY}

Events are a fundamental aspect of people's cultures and traditions (Allen, O'Toole, Harris, \& McDonnell, 2008:5; Bowdin, Allen, O’Toole, Harris, \& McDonnell, 2006:3). Festivals and events have marked the momentous and meaningful occasions in people's lives, such as birthdays, deaths, changes of seasons, religious holidays, new year celebrations, contests and more (Allen et al., 2008:5; Bowdin et al., 2006:4; Tassiopoulos, 2005a:2). With increased media coverage and exposure, the event sector has grown in numbers, popularity and variety, and events and festivals are one of the highest emergent tourist attractions globally (Gursoy et al., 2004:171-172), with 'event tourism' as an established sector within the international tourism industry (Getz, 1989:133; Getz, 2008:405; Tassiopoulos, 2005a:4).

\section{SUSTAINABLE URBAN EVENT PRACTICE}

\section{Sustainable development defined}

A well known and accepted definition of sustainable development is that of the World Commission on Environment Development's (WCED's) Brundtland Report in 1987, which states that sustainable development is "development that meets the needs of the present without compromising the ability of future generations to meet their own needs" (WCED in Queiros, 2003:74).

The human population is increasing at a substantial rate, which consequently leads to an increasing demand for natural resources; greater than which the ecosystem can provide for (Reid, 2006:208). This increased demand causes the destruction of the natural 
environment, exploitation of natural resources, pollution and loss of habitat of fauna and flora (Queiros, 2003:74). The concept of sustainable development originated from this scenario, as governments, organisations and individuals attempted to practice development that could potentially avoid or improve the environmental crisis (Queiros, 2003:74), therefore the World Commission on Environment Development's definition promotes careful use and conservation of the natural environment and its resources.

Sustainable development is a process that must be made reliable for, and consistent with future needs as well as present needs (WCED in Wight, 2004:48). Wight (2004:48) argues that there are five interrelated elements of sustainable development, namely: economic: the generation of wealth and employment opportunities and the enhancement of material life; political: the political stability of a destination, safety and security and human rights; social: the well-being of the local community in terms of education, health, nourishment and shelter; cultural: the acknowledgment of and respect for heritage and traditions, as well as the support of cultural identity; and ecological/environmental: the recognition of the importance of conservation of all natural resources and environmental enlightenment and understanding.

Sustainable development can briefly be defined as development that is concerned with the protection of the environment and all its resources, the well-being of the local community and respect for their culture, and the creation of economic benefits for all stakeholders involved, in order to ensure a positive outlook for future generations.

\section{Sustainable tourism defined}

The tourism industry is largely dependent on the environment and its resources, both natural and cultural. For tourism to occur, tourists must be present at the destination and/or attraction/event and may largely impact on the environment and the host community. To reduce negative impacts and create positive results and opportunities, tourism must be implemented and managed accordingly (Queiros, 2003:74).

In essense sustainable tourism is the application of the concept of sustainable development within the tourism industry. "Sustainable tourism development meets the needs of the present tourists and host regions while protecting and enhancing 
opportunities for the future" (The World Tourism Organisation in Dickson \& Arcodia, 2010:237). The manner in which resources are controlled guarantees the satisfaction of social and economic needs whilst preserving cultural and natural diversities (The World Tourism Organisation in Dickson \& Arcodia, 2010:237). According to Queiros (2003:74), sustainable tourism development is tourism that is established and preserved in such a way that it is economically viable over the long-term, while at the same time does not deplete, destroy or change the natural and socio-cultural environments on which it depends. Sustainable tourism development is essential to ensure that the interactions and relationships between the natural, socio-cultural and economic environments are in a constant state of balance (i.e. where the three environments overlap), refer to Figure 1 (Queiros, 2003:75).

Figure 1: Sustainable tourism development

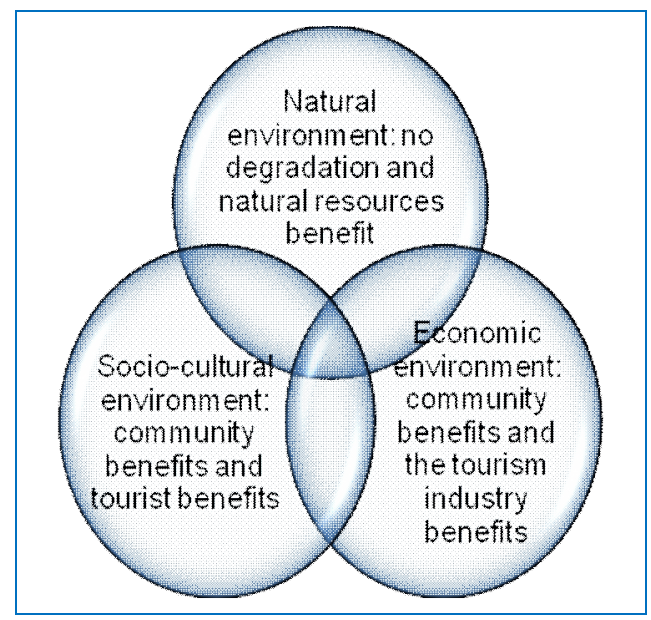

Source: Queiros (2003:75).

\section{Sustainability and events}

The tourism industry and the events sector are entwined, as events create a means to draw tourists to a destination. However with climate change, the events sector has recently created concern with its generation of waste and its consequent negative impact on climate change (Dickson \& Arcodia, 2010:236). Sustainable tourism development principles and strategies need to be implemented within the events sector to minimise negative impacts on the environment (Dickson \& Arcodia, 2010:236-237). Although events present potential social, cultural, economic and educational benefits, as well as prospective tourism development for a destination (Dickson \& Arcodia, 2010:236), they must be economically, socially and environmentally sustainable. 
- Economic sustainability: The main aim of most events is to generate economic benefits and make a profit (Getz, 2008:419; Salem, Jones \& Morgan, 2004:16). Events promote and build a positive image for the host destination, generate tourist growth and boost economic development within the destination (Tassiopoulos, 2005a:3). A successful event has the potential to motivate tourists to extend their stay at a destination, which results in higher tourist yield. Events provide employment opportunities for the local community, and also encourage locals to start their own businesses or develop new facilities for the purpose of tourism, for example arts and crafts. This increases commercial activity within the region and so increases tax revenue. These economic benefits raise the standard of living of the local community, and in turn contribute to economic development of the country or destination (Allen et al., 2008:64; Bowdin et al., 2006:50-52; Gursoy et al., 2004:175). However, events also generate economic costs, such as increases in costs of products and services used by the host community (Gursoy et al., 2004:173). If an event is not managed and executed in a sustainable manner, this may result in potential failure and damage the image and reputation of the destination, create community resistance and resentment towards tourism, and ultimately result in financial loss (Allen et al., 2008:64).

- Socio-cultural sustainability: A successful event rejuvenates a destination's cultural traditions, promotes its characteristics and renews the local community's pride and confidence (Tassiopoulos, 2005a:3). According to Getz (in Gursoy et al., 2004:171), events play an important role in locals' lives, as they offer essential activities and spending channels for locals and tourists, and improve the local community's image. Events are the catalysts of a local community's well-being and improvement (Getz in Derrett, 2004:32) and the success of events depends greatly on the involvement, passion and support of the local community (Gursoy et al., 2004:171). Therefore, positive social benefits of events must be generated and encouraged. Festivals and events are interactive experiences and build social cohesion and togetherness and strengthen the community as a unit (Gursoy et al., 2004:173). Events offer a chance for cultural exchange, which raises cultural awareness and understanding between event tourists and locals (Gursoy et al., 2004:173). Socially sustainable events establish trust and create a sense of belonging among community members and also 
help to preserve local traditions and heritage (Allen et al., 2008:64; Bowdin et al., 2006:38; Gursoy et al., 2004:171-175). However, should sustainable event practice not be implemented, crowding, congestion and crime rates could increase, which may lead to a negative event experience for tourists and the local community. Local traditions and cultures may also be exploited for the purpose to attract tourists. This could decrease cultural authenticity and cause locals to resent tourists. If communities are not actively involved in the planning and decision-making of the event, they may feel alienated and cultural disrespect may result. Ultimately, the destination will develop a negative image (Allen et al., 2008:64; Getz, 2008:412; Gursoy et al., 2004:175).

- Environmental sustainability: Events and environmental impacts have seldom been the topic of discussion, and when they have been considered as one topic, only the negative impacts of events on the environment have been examined (Dickson \& Arcodia, 2010:237). Events and festivals usually entail a large number of people in a restricted geographical area for a specific period of time, which cause congestion, pollution, wastage of water and resources and noise (Collins et al., 2009:829). If not managed properly, events can negatively impact ecosystems through utilisation of non-renewable natural resources and contribute to carbon emissions and eventually climate change (Collins et al., 2009:829). Events however can also be a medium to promote environmental awareness, responsibility and understanding among event tourists, the local community, and the rest of the tourism sector as well as other business sectors (Collins et al., 2009:829). Sustainable event practice can also encourage development of environmentally-friendly transport systems and infrastructure, waste management and recycling, alternative eco-friendly energy sources and potentially enhance the environment (Allen et al., 2008:64; Collins et al., 2009:830).

Events, if planned and managed in a sustainable manner, are able to enhance local pride, identity and well-being, create a positive image of the destination, promote conservation of the environment and local heritage, generate employment opportunities, boost urban renewal and economic benefits (Derrett, 2004:33; Getz, 2008:405; Tassiopoulos, 2005a:3). 


\section{THE ROLE OF CORPORATE SPONSORS IN PROMOTING SUSTAINABLE URBAN EVENTS}

\section{Sponsorships defined}

A sponsor is any organisation or corporation that provides finances, services or some kind of support in exchange for particular benefits (Getz in Tassiopoulos, 2005b:40). George (in Nunstu \& Shukla, 2005:174) argues that sponsorship is "the provision of financial or material support by a company for some independent activity (usually related to sport or art) not usually directly linked to the company's normal business, but support from which the sponsoring company would hope to benefit". Sponsorship differs according to the event type, the cost of the event, the degree of expert planning and goals, number and nature of event visitors, media exposure and location (Mack in Nunstu \& Shukla, 2005:174). A sponsorship is a strategic marketing tool for both the sponsor company and the event organisation (Allen et al., 2008:346; Nunstu \& Shukla, 2005:174). Therefore, a sponsorship is support of some kind provided by a company to ensure a successful event, and provides benefits for both the sponsor company and the event organiser.

\section{Sponsorships and urban events}

The shift from viewing sponsorships as a public relations strategy for generating goodwill to considering sponsorships as the prime promotional instrument for events is evident (Allen et al., 2008:135). If the sponsorship agreement is well-designed and implemented, it will provide benefits to the host community (Nunstu \& Shukla, 2005:175).

Sponsorships have become increasingly important in the events industry (Nunstu \& Shukla, 2005:175) with advertising becoming a more memorable and powerful marketing tool when the sponsor company is incorporated in the event's advertising material (Nunstu \& Shukla, 2005:175-176). Changing social concerns result in sponsorships aligning the sponsor companies and event companies with social responsibility, which attracts the attention of customers (Nunstu \& Shukla, 2005:176). Sponsorships motivate people to attend events by emphasising their contribution to social improvement that increases environmental awareness. Sponsorship is viewed positively as all stakeholders involved benefit, and is more widely accepted than traditional advertising (Nunstu \& Shukla, 2005:176). 
Sponsorships provide a means to influence the public and increase awareness of the event and the sponsor company's product and corporate identity (Nunstu \& Shukla, 2005:176). When a sponsorship implements sustainable business practice and promotes conservation, public awareness of the environment and the importance of conservation is enhanced, resulting in greater public support for the event. Sponsorships also provide benefits to the local community by involving them (Nunstu \& Shukla, 2005:176-177).

Sponsorships should promote sustainable event practice as they have access to particular target markets; enhance the brand image of the event (if the sponsor company is well known and established within the community) and finally have the potential to build and increase brand awareness, and social responsibility and generate goodwill (Allen et al., 2008:353).

Figure 2 represents the direct relationship between the three main event role players, namely the event company, the sponsor and the event tourists and/or local community (Tassiopoulos, 2005b:38).

Figure 2: The event triangle: key event role players

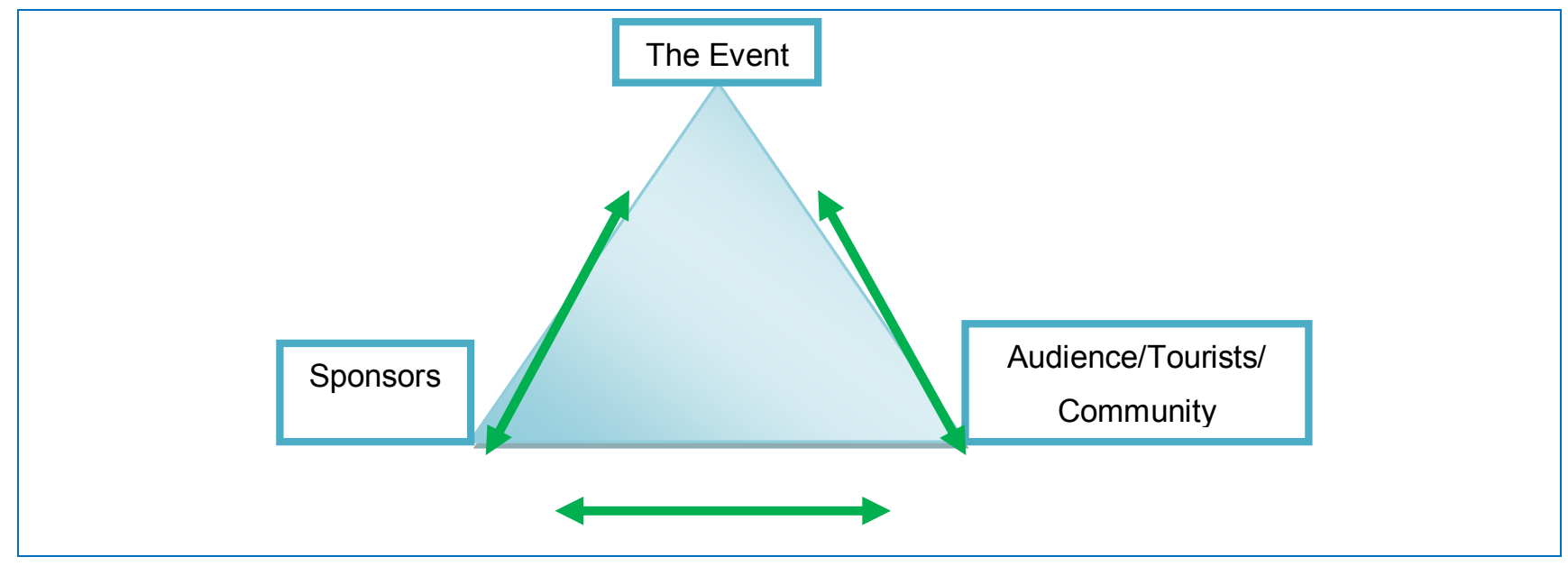

Source: Tassiopoulos (2005:38).

Sponsors have a direct influence on the event itself and the event company, and can inform the event company on sustainability and encourage them to implement sustainable event practice. As sponsors also have a direct influence on the event tourist they can educate the public on the importance of sustainable event practice and promote environmental consciousness, conservation and cultural awareness, and encourage community involvement allowing all event stakeholders to benefit. 


\section{METHODOLOGY}

The target population consisted of employees of companies that sponsor events, with head offices within Gauteng province. The employees were individuals (managerial and/or non-managerial) that handle the event sponsorship and have direct influence regarding the organising, promoting and media advertising of the event. The events the companies sponsor range from national to international events, sports events, outdoor events and art and music festivals. The units of analysis were the individual employees.

The qualitative nonprobability sampling method was followed (Cooper \& Schindler, 2008:169) that deals with small samples that have purposefully been selected (Guest, Bunce \& Johnson, 2006:61; Patton, 2002:230). The "logic" and "power" of purposeful sampling requires the selection of "information-rich cases" (Patton, 2002:230), with purposeful sampling regarded as the most appropriate to gain in-depth insight into and an understanding of sustainable event practice. An accurate sampling frame is not available.

A sample size of ten respondents was established to obtain rich detailed data and information-rich results. Patton (2002:244-45) argues that the validity, significance and insights produced from qualitative research, rely more on the information richness of the chosen cases than on the size of the sample; whereas Guest et al. $(2006: 59,65)$ argue that sample size depends on "data saturation" that can be described as the point in data collection and analysis where no new information is observed by the researcher. The ten interviews were conducted between 1 October-6 November 2010 using a semi-structured interview schedule, and data collected was deemed reliable and detail-rich, and reached the point where no new data was observed.

\section{LIMITATIONS}

The small sample size is a limitation although the focus was on obtaining information-rich data from a small number of selected individuals. As nonprobability sampling is a subjective approach, there was a greater possibility for bias to be introduced into the sample selection process, which could distort the research results (Cooper \& Schindler, 2008:395). Other limitations might be related to collecting the data as not all respondents understood the concept of sustainability as fully as others. Research results were drawn 
collectively rather than for each individual participant, and might have been distorted. The findings cannot be generalised to the larger population.

\section{RESULTS}

The narrative data analysis process was followed (Taylor-Powell \& Renner 2003:2) with a detailed process of evaluation and interpretation to transfer the data into meaningful information. Themes and patterns within the data emerged and were organised into relevant categories that corresponded with the initial research questions.

In relation to clarifying the concept of a 'sustainable' event, half of the respondents considered an event to be sustainable if it generates profits and return on investment, involves long-term commitment and strategy, generates long-lasting benefits for all stakeholders involved; creates awareness of sustainability; and educates event visitors; with the rest of the respondents including elements of the natural environment, sociocultural environment and economic environment as an integrated concept. Only several respondents confirmed to their companies having a formal sustainability policy.

In terms of addressing (the research question posed) as to what the role is of corporate sponsors in promoting sustainable urban event practice and creating public awareness, it is clear from the findings, that corporate event sponsors do indeed play a role in promoting sustainable event practice. Event sponsors have an influence over the public, and by knowing who their target market is, as well as that of the event, they have a greater chance of creating valuable consumer associations with sustainable event practice. Accordingly they can create and raise awareness on sustainability, change perceptions on sustainability, and enlighten the general public as well as event stakeholders on the importance of sustainable event practice, in some respondents' narratives: ““...if your audience loves soccer and you sponsor community soccer, you will draw attention and influence perceptions."; [and in] "sponsoring brands with which people can associate and relate to, [sustainable events can] create awareness and positive perceptions...”. Several respondents highlight the influence of event sponsorships with regard to "awareness", "association" and "perceptions": "...we show the public that we're involved and that we support what they love and what they're passionate about. In this way they support us and become our loyal customers...”; [event sponsorships] “...can influence or change their (the 
consumer's) perceptions of the company and the event." From the above it can be assumed that the perceptions and associations of the consumers include positive feelings about sustainable event practice.

In terms of creating public awareness, several (six) of the respondents stated that the general public perceived sustainable events in a positive light, however, less than half (four) of the respondents believe that the general public has a limited awareness and understanding of sustainability and sustainable event practice, and accentuated the need to increase awareness on the issue. Respondents stated that: "South Africa doesn't have sustainability as a priority..[one must] start off by creating awareness to express the urgency of the issue...". As one respondent stated: "I'm not sure of how many people are actually aware of sustainability...there is a need to raise awareness...; [however]...there is a limited awareness of such events...; several respondents felt that "most people are still naïve; especially in the country...one must constantly create awareness..."In addition, the majority of respondents (seven) believed that event sponsors create public awareness of an event and stimulate interest in that event. Furthermore, half of the respondents stated that if consumers associated with and connected to the sponsoring brand, the brand could influence perceptions and attract attention to the event.

The majority (eight) of the respondents stated that consumer association with the sponsoring brand will draw interest to an event. Corporate sponsors must know who their target audience is, as well as that of the event, in order to create positive consumer associations and awareness on sustainable event practice. In addition, several (seven) of the respondents stated that their companies sponsor events where the community will benefit in some way. Thus, corporate sponsors can raise awareness of the importance of sustainability and enlighten community members on sustainable event practice, through active participation in the sustainable event. This will lead to the creation and equal distribution of benefits for all involved.

With regard to how corporate sponsors can enlighten event companies on the importance of sustainable event practice and encourage them to pursue it, the findings suggest that sustainable event practice is increasingly important in today's society and attractive for businesses, as it generates revenue, creates positive socio-cultural impacts on the 
community, ensures the conservation and protection of the natural environment; and is beneficial to all stakeholders. In addition, sustainable events can make event stakeholders aware of sustainability and its importance. Several respondents feel that it "...can generate a long-lasting, sustainable benefit..."; takes the well-being of the community and the environment into consideration."; "is not harming the environment through the staging of the event...educating visitors on sustainability."; and "...an event would be sustainable provided that the environmental, social, cultural, and economic matters are integrated..."

The findings imply that sustainability is a significant and measurable element of a company's success and reputation. Most (eight) of the respondents state that sustainable business practice, which includes event practice, is essential to ensure the long-term growth and success, not only of the sponsoring company and the event, but of the economy as well. One participant stated that the importance of sustainability will only continue to grow in the future and should become law-enforced; with several (six) of them stating that their company has a formal event sustainability policy.

Most (nine) of the respondents agreed that events seek sponsorship in order to gain resources, whether financial or material, to enable the event to take place. Moreover, several (seven) of the respondents agreed that sponsorship will increase exposure and raise awareness of the event. Therefore, the main reason why an event would succeed would be owed to the corporate sponsor; without their contribution of financial aid and/or increased marketing, the event would not occur or deliver a quality experience to its visitors or consumers. Furthermore, half of the respondents believe that events associated with high profile or well-known brands will lift the profile of the event and generate more interest. Corporate sponsors should develop long-term relationships with the event organisations to build trust. They should emphasise the potential benefits of the sponsoring partnership and encourage the event organisations to implement sustainable event practice.

Most respondents are of the opinion that corporate sponsors can promote sustainable event practice: "...because if they fund the event, they can require sustainable practices...and can request the use of sustainable materials, consumer education at the event and sustainability audits...". Therefore since sponsors are the main financial 
contributor to an event, they can insist on sustainable event practice based on certain criteria, which will raise awareness of sustainability among event stakeholders, including the event organisation, as well as the general public.

\section{FINDINGS}

Consistent with the literature, the findings of this study show that events do indeed present impacts on the natural environment, the social-cultural environment and the economic environment of a destination. The results indicate that sustainable urban events generate profits and return on investment which contributes positively to the economy and event stakeholders; they have a positive impact on the community and their well-being; and they promote conservation and protection of the natural environment. These findings are supported by evidence in the literature review. According to Getz (2008:419) and Salem et al. (2004:16) events produce economic benefits, in terms of revenue and profits. In addition, Getz (in Derrett, 2004:32) describes events as catalysts of the local community's well-being and improvement, throughthe creation of employment opportunities. They also encourage locals to start their own businesses for the purpose of tourism and in doing so they generate benefits for themselves and the economy (Allen et al., 2008:64; Bowdin et al., 2006:50-52; Gursoy et al., 2004:175). As discussed by Collin et al. (2009:829) events require a large number of people to gather in a restricted area for a period of time, therefore they negatively impact the environment.However, in order to minimise the potential negative impacts and maximise the positive impacts of events, and ensure that all event stakeholders benefit, sustainable event practice must be implemented to ensure balance between all three environments. Findings are also congruent with the fact that events can be used to promote environmental awareness, responsibility and enlightenment among event stakeholders and the general public (Collins et al., 2009:829). Lastly, as the definition of sustainability emphasises (WCED in Queiros, 2003:74) findings indicate that sustainability and sustainable event practice requires long-term commitment from the sponsor and the event organisation, and strategy to generate long-lasting benefits for all stakeholders. So, taking everything into consideration sustainable event practice is an integrated concept and is important as it creates positive economic benefits for all event stakeholders; it supports the well-being and development of the local community; it protects the natural environment and its resources; it promotes environmental awareness and educates stakeholders on sustainability; finally, sustainable event practice requires a 
long-term vision, understanding and commitment by all stakeholders to guarantee future prosperity for all.

With regard to corporate sponsors, and their role in promoting sustainable urban event practice, findings imply that sponsors are responsible for a great deal of awareness and interest created around a specific event, and that consumer association with that sponsor plays a big role in attracting attention to that event. These results are supported by Nunstu\& Shukla $(2005: 175)$ who state that sponsorships play an increasingly important role in the event industry, as consumers are more drawn to the event's promotional media that featuresthe sponsoring company.Furthermore, from the literature (Nunstu \& Shukla, 2005:176), as well as from the results, it is clear that sponsorships are capable of influencing positive perceptions on sustainable event practice.Thus, as both research results and existing literature suggest (Allen et al., 2008:353), sponsorships have a responsibility to promote sustainable event practice and enlighten stakeholders and the public on the issue, because they have greater access to their existing and potential target markets that the event organiser does not; they enhance the brand image of the event, therefore stimulating more interest in the sustainable event; and they have the resources (expertise and finances) to create and raise awareness.

The results with respect to the how sponsors can enlighten the general public on sustainable event practice and the importance of sustainability indicate that consumer association with the sponsor plays a big role in stimulating interest in the event and influencing consumers' perceptions on the matter of sustainability. These findings are in line with Nunstu \& Shukla's (2005:176) argument that sponsorships motivate people to attend events by emphasising that they too can contribute to a greater cause and conserve the environment; hence, this raise environmental consciousness. In addition, Tassiopoulos (2005:38) argues that there is a direct relationship between a sponsor and the local community and event tourists; therefore they can enlighten the public on the importance of sustainable event practice. Research findings show that through benefiting the community in some way and involving them in the event, sponsors can raise awareness of sustainability among community members, which will spread to the general public and draw increased attention to the sustainable event. 
The impact of corporate sponsors on the event organisation is direct, as illustrated by Tassiopoulos (2005:38). As findings indicate, corporate sponsors are the main financial contributor to an event and create increased exposure for that event; so they have, and should have a direct influence over the event organisation. Thus, sponsors can enlighten the event organisation on the importance of sustainability and encourage them to implement sustainable event practice, through recycling at the event, conserving water, minimising their carbon emissions and involving the community. Sponsors can also establish sustainable event criteria, and enter into ethical partnerships with event organisations, which will ultimately draw more attention to the event. This is consistent with Nunstu \& Shukla (2005:176) who state that due to shifting social concerns, sponsorships can align the sponsor company and the event organisation with social responsibility, which creates awareness and draws customers' attention to the event.

\section{CONCLUSION}

As the literature emphasises, and with which the research results are congruent, sustainable event practice is an integrated concept that requires all stakeholders to be involved; in this way all stakeholders will benefit. As results indicate, sustainability is the way of the future, and will continue to grow in importance. Due to the significant influence of sponsors over the public and the event organisations, as well as their great market reach, they play a vital role in promoting sustainable event practice and creating awareness and understanding of sustainability.

Today, society realises the significance of sustainability, and that it is the way of the future.In order to grow and succeed in business and enhance their image and reputation, managers of companies and event organisations must understand the meaning and importanceof sustainability and the great deal of benefits associated with sustainable event practice.It is essential that event organisations and event sponsors work together to develop a formal accreditation programme for sustainable events. This will enable event organisers and sponsors to benchmark themselves against others in the industry and determine where improvements can be made. Accreditation will also create awareness among consumers and stimulate interest in the event. Furthermorea specific set of sustainable guidelines should be established that are adaptable to each individual event. This consistency and uniformity will provide clarity and direction for event organisations 
and make the task seem like less of an effort, and therefore attract more event organisers and sponsors to engage in sustainable event practice.It is therefore essential that the sponsors and managers of event companies work together to develop sustainable urban event guidelines and policies and a formal accreditation programme within the industry.

\section{REFERENCES}

Allen, J., O'Toole, W., Harris, R. \& McDonnell, I. 2008: Festival and special event management. $4^{\text {th }}$ ed. (Wiley Australia tourism series), Wiley, Australia.

Botha, C. 2003: The importance and role of attractions in the tourism industry. In: Lubbe, B.A. (ed.) Tourism management in Southern Africa. Pearson Education, Cape Town.

Bowdin, G.A.J., Allen, J., O'Toole, W., Harris, R. \& McDonnell, I. 2006: Events management. $2^{\text {nd }}$ ed. (Events management series). Butterworth-Heinemann, Oxford.

Brown, S. \& James, J. 2004: Event design and management: ritual sacrifice? In: Yeoman, I., Robertson, M., Ali-Knight, J., Drummond, S. \& McMahon-Beattie, U. (eds.) Festival and events management: an international arts and culture perspective. Elsevier, Massachusetts.

Bryman, A. \& Bell, E. 2007: Business research methods. $2^{\text {nd }}$ ed. University Press, Oxford.

Budeanu, A. 2005: Impacts and responsibilities for sustainable tourism: a tour operator's perspective. Journal of Cleaner Production, 13(2):89-97. [Online] Available from: ScienceDirect:http://0-www.sciencedirect.com.innopac.up.ac.za/

science?_ob=ArticleListURL\&_method=list\&_ArticleListID $=1251331645 \&$ sort=r\&view=c\&_acct=C 000005298\&_version=1\&_urlVersion=0\&_userid=59388\&md5=1b47e506b89faf 1 ef708027c46f9de 05[Downloaded: 2010-03-07].

Collins, A., Jones, C. \& Munday, M. 2009: Assessing the environmental impacts of mega sporting events: two options? Journal of Tourism Management, 30(6):828-837. [Online] Available from: ScienceDirect: http://0-www.sciencedirect.com.innopac.up.ac.za/science?_ob= ArticleListURL\&_method=list\&_ArticleListID=1251333712\&_sort=r\&view=c\&_acct $=C 000005298 \&$ 
version=1\&_urlVersion=0\&_userid=59388\&md5=4611e26577daf0000e7c717391 cee38d[Downloa ded: 2010-03-01].

Cooper, D.R. \& Schindler, P.S. 2008: Business research methods. $10^{\text {th }}$ ed. McGraw-Hill, New York.

Creswell, J.W. 2009: Research design: qualitative, quantitative and mixed methods approaches. $3^{\text {rd }}$ ed. Sage, London.

Derrett, R. 2004: Festivals, events and the destination. In: Yeoman, I., Robertson, M., AliKnight, J., Drummond, S. \& McMahon-Beattie, U. (eds.) Festival and events management: an international arts and culture perspective. Elsevier, Massachusetts.

Dickson, C. \& Arcodia, C. 2010: Promoting sustainable event practice: the role of professional association. International Journal of Hospitality Management, 29(2):236-244. [Online] Available from: ScienceDirect: http://0-www.sciencedirect.com.innopac.up.ac.za/ science?_ob=ArticleListURL\&_method=list\&_ArticleListID=1251327823\&_sort=r\&view=c\&_acct=C 000005298\&_version=1\&_urlVersion=0\&_userid=59388\&md5=16af26f5ffb39a63efaff51f740218b7 [Downloaded: 2010-03-04].

Getz, D. 1989: Special events: defining the product. Journal of Tourism Management, 10(2):125-137. [Online] Available from: ScienceDirect: http://0www.sciencedirect.com.innopac.up.ac.za/science?_ob=ArticleListURL\&_method=list\&_Art icleListID=1251288479\&_sort=r\&view=c\&_acct=C000005298\&_version=1\&_urlVersion=0 \&_userid=59388\&md5=d8461b1b9600eea4f0623339b2297a3a [Downloaded: 2010-0304].

Getz, D. 2008: Event tourism: definition, evolution, and research. Journal of Tourism Management, 29(3):403-428. [Online] Available from: ScienceDirect: http://0www.sciencedirect.com.innopac.up.ac.za/science?_ob=ArticleListURL\&_method=list\&_Art icleList ID=1251338205\&_sort=r\&view=c\&_acct=C000005298\&_version=1\&_urlVersion=0 \&_userid=59388\&md5=40e73157e16a90f4380e1898420d8187 [Downloaded: 2010-0226]. 
Gratton, C., Shibli, S. \& Coleman, R. 2005: The economics of sport tourism at major sports events. Journal of Sport Tourism Destinations, 233-244. [Online] Available from: ScienceDirect: http://0-www.sciencedirect.com.innopac.up.ac.za/science? _ob=ArticleListURL\&_method=list\&_ArticleList ID=1289490395\&_sort=r\&_st=4\&_acct=C00000529 8\&_version=1\&_urlVersion=0\&_userid $=59388 \& \mathrm{md} 5=531$ e34bb098f26cda3bcdd7 a5031198d [Accessed: 2010-04-03].

Guest, G., Bunce, A. \& Johnson, L. 2006: How many interviews are enough? An experiment with data saturation and variability. Field Methods. [Online] Available from: Sage: http://www.sagepub.com/cgi/content/abstract/18/1/59 [Downloaded: 2010-05-09].

Gursoy, D., Kim, K. \& Uysal, M. 2004: Perceived impacts of festivals and special events by organizers: an extension and validation. Journal of Tourism Management, 25(2):171-181. [Online] Available from: ScienceDirect: http://0-www.sciencedirect.com.innopac.up.ac.za /science?_ob=ArticleListURL\&_method=list\&_ArticleList|D=1251336331\&_sort=r\&view=c\&_acct=C 000005298\&_version=1\&_urlVersion=0\&_userid $=59388 \& \mathrm{md} 5=370481$ e56e0e20d954a283df4d23 a375[Downloaded: 2010-03-04].

Hunter, C. \& Shaw, J. 2007: The ecological footprint as a key indicator of sustainable tourism. Journal of Tourism Management, 28(1):46-57. [Online] Available from: ScienceDirect: $\quad$ http://0-www.sciencedirect.com.innopac.up.ac.za/science?_ob= ArticleListURL\&_method=list\&_ArticleList $\mid \mathrm{D}=1251336331$ \&_sort=r\&view=c\&_acct=C000005298\&_ version=1\&_urlVersion=0\&_userid=59388\&md5=370481e56e0e20d954a283df4d23a375

[Downloaded: 2010-03-02].

Laing, J. \& Frost, W. 2010: How green was my festival: exploring challenges and opportunities associated with staging green events. International Journal of Hospitality Management, 29(2):261-267. [Online] Available from: ScienceDirect: http://0www.sciencedirect.com.innopac.up.ac.za/science?_ob=ArticleListURL\&_method=list\&_ArticleListl $D=1289485754 \&$ view=c\&_acct=C000005298\&_version=1\&_urlVersion=0\&_userid=59388\&md5=9 2a7940efbce9026614be2f405036176[Downloaded:

2010-02-20]. 
Nunstu, N. \& Shukla, N. 2005: Event sponsorship. In: Tassiopoulos, D. (ed.) Event management: a professional and developmental approach. $2^{\text {nd }}$ ed. Juta, Cape Town.

Patton, M.Q. 2002: Qualitative research and evaluation methods. $3^{\text {rd }}$ ed. Sage, San Francisco, USA.

Queiros, D. 2003: The natural resource base. In: Lubbe, B.A. (ed.) Tourism management in Southern Africa. Maskew Miller Longman, Cape Town.

Reid, R.E. 2006: A journey to define sustainability: Waterton Lakes National Park. In: Herremans, I.M. (ed.) Cases in sustainable tourism. Haworth Hospitality Press, New York.

Salem, G., Jones, E. \& Morgan, N. 2004: An overview of events management. In: Yeoman, I., Robertson, M., Ali-Knight, J., Drummond, S. \& McMahon-Beattie, U. (eds.) Festival and events management: an international arts and culture perspective. Elsevier, Massachusetts.

Sandelowski, M. 1994: Focus on qualitative methods: sample size in qualitative research. [Online] Available from: University of Pretoria: https://elearn.up.ac.za/webct/urw/lc4130011.tp0/cobaltMainFrame.dowebct?appforward=u rw/lc1591836538031.tp1592734601031/startFrameSet.dowebct\%3Fforward=studentCour seView.dowebct\%26lcid=1591836538031 [Downloaded: 2010-05-09].

Saunders, M., Lewis, P. \& Thornhill, A. 2007: Research methods for business students. $4^{\text {th }}$ ed. Pearson, Harlow, UK.

Tassiopoulos, D. 2005a: Events: an introduction. In: Tassiopoulos, D. (ed.) Event management: a professional and developmental approach. $2^{\text {nd }}$ ed. Juta, Cape Town.

Tassiopoulos, D. 2005b: Event role players. In: Tassiopoulos, D. (ed.) Event management: a professional and developmental approach. $2^{\text {nd }}$ ed. Juta, Cape Town. 
Wight, P.A. 2004: Practical management tools and approaches for resource protection and assessment. In: Diamantis, D. (ed.) Ecotourism: management and assessment. Thomson, London.

Taylor-Powell, E. \& Renner, M. 2003: Analyzing qualitative data. University of Wisconsin. [Online] Available from: http://learningstore.uwex.edu/Assets/pdfs/G365812.pdf[Downloaded: 2010-07-31]. 